\title{
Characterization of catechol 2,3-dioxygenase from Planococcus sp. strain S5 induced by high phenol concentration"
}

\author{
Katarzyna Hupert-Kocurek, Urszula Guzik ${ }^{\bowtie}$ and Danuta Wojcieszyńska \\ Department of Biochemistry, Faculty of Biology and Environmental Protection, University of Silesia in Katowice, Katowice, Poland
}

This study aimed at characterization of a new catechol 2,3-dioxygenase isolated from a Gram-positive bacterium able to utilize phenol as the sole carbon and energy source. Planococcus sp. strain S5 grown on 1 or $2 \mathrm{mM}$ phenol showed activity of both a catechol 1,2- and catechol 2,3-dioxygenase while at a higher concentrations of phenol only catechol 2,3-dioxygenase activity was observed. The enzyme was optimally active at $60^{\circ} \mathrm{C}$ and $\mathrm{pH}$ 8.0. Kinetic studies showed that the $K_{\mathrm{m}}$ and $V_{\max }$ of the enzyme were $42.70 \mu \mathrm{M}$ and $329.96 \mathrm{mU}$, respectively. The catechol 2,3-dioxygenase showed the following relative meta-cleavage activities for various catechols tested: catechol $(100 \%)$, 3-methylcatechol (13.67\%), 4-methylcatechol (106.33\%) and 4-chlorocatechol (203.80\%). The high reactivity of this enzyme towards 4-chlorocatechol is different from that observed for other catechol 2,3-dioxygenases. Nucleotide sequencing and homology search revealed that the gene encoding the S5 catechol 2,3-dioxygenase shared the greatest homology with the known genes encoding isoenzymes from Gram-negative Pseudomonas strains.

Keywords: catechol 2,3- dioxygenase, phenol degradation, Planococcus

Received: 17 January, 2012; revised: 17 March, 2012; accepted: 16 July, 2012; available on-line: 14 July, 2012

\section{INTRODUCTION}

Many bacteria and other microorganisms can grow on various aromatics like benzene, naphthalene, phenol and its derivatives, as the sole source of carbon and energy. Under aerobic conditions biodegradation of aromatic compounds involves their conversion into dihydroxylated intermediates (e.g., catechol or its alkyl- or chlorosubstituted derivatives) which are then further metabolized by intradiol or extradiol dioxygenases (Bugg, 2003; Palaniandavar \& Mayilmurugan, 2007). These ring-cleaving enzymes catalyze the addition of both atoms of molecular oxygen into the aromatic ring (Okuta et al., 1998). The intradiol enzymes incorporate the two oxygen atoms between the vicinal hydroxyl groups, while the extradiol dioxygenases cleave the aromatic ring of the substrate outside the two hydroxyl groups and produce muconic semialdehyde (Viggiani et al., 2004; Kalogeris et al., 2006). Under aerobic conditions microbial biodegradation of phenol can occur either through the ortho or the meta pathway (Harayama \& Rekik 1989; Bugg, 2003; Fortin et al., 2005; Bugg \& Ramaswamy, 2008).

Due to their key role in the degradation of aromatic ring, intradiol and extradiol dioxygenases have been extensively studied in the last decades. Catechol 2,3-dioxygenases (C23Os) belong to the extradiol dioxygen- ases family. To data, they have been found in numerous Gram-negative (Pseudomonas, Sphingomonas, Acinetobacter, Ralstonia, Burkbolderia, Stenotrophomonas) and Gram-positive (Nocardia, Rhodococcus and Bacillus) strains (Müller et al., 1996; Milo et al., 1999; Sei et al., 1999; Jiang et al., 2004; Junca et al., 2004; Li et al., 2004; Viggiani et al., 2004; Kim et al., 2005; Kasuga et al., 2007; Ma et al., 2010; Wei et al., 2010; Tancsics et al., 2010; Wojcieszyńska et al., 2011). All known catechol 2,3-dioxygenases are homotetramers. Most of them contain non-heme iron Fe (II) in their active site but some are also active with Mn (II) (Sato et al., 1997; Bugg, 2003; Hatta et al., 2003; Viggiani et al., 2004; Vaillancourt et al., 2006).

Planococcus sp. strain S5, a Gram-positive bacterium isolated from activated sludge from a sewage treatment plant in Bytom Miechowice, Poland, is able to grow on salicylate or benzoate (Labużek et al., 2003). As we previously reported, the S5 strain grown on salicylate expressed both catechol 1,2-dioxygenase and catechol 2,3-dioxygenase activities, while when grown on benzoate it only expressed catechol 1,2-dioxygenase activity. To date, only two Planococcus strains have been reported to degrade aromatic compounds: Planococcus sp. strain ZD22 and Planococcus sp. (Li et al., 2006; Dalal et al., 2012). In 2001, Engelhardt et al. described Planococcus alkanoclasticus sp. nov. isolated from intertidal beach sediment capable of degrading linear alkanes but not aromatic hydrocarbons. Most of the Planococcus bacteria are known to be moderately halophilic (Romano et al., 2003; Sprott et al., 2003; Li et al., 2006). Moreover, some of these strains show heavy metal resistance (Chowdhury et al., 2003; Nithya et al., 2011) and an ability to produce surfactants (Jacobucci et al., 2009). Because of the above properties, bacteria from the genus Planococcus could be useful in bioremediation of extreme contaminated environments.

In this study we present the ability of Planococcus strain S5 to degrade phenol by using catechol 1,2-dioxygenase and catechol 2,3-dioxygenase or only catechol 2,3-dioxygenase depending on the initial aromatic substrate concentration. The main aim of our work was to identify and characterize the catechol 2,3-dioxygenase of strain S5. The high reactivity of this enzyme towards 4-chlorocatechol distinguishes this protein from previously characterized catechol 2,3-dioxygenases. The nucleotide sequence of the isolated gene for $\mathrm{C} 23 \mathrm{O}$ from the Plano-

e-mail: urszula.guzik@us.edu.p

\#GenBank ID: HQ223337

Abbreviations: C23O, catechol 2,3-dioxygenases; C12O, catechol 1,2-dioxygenases; CCMA, cis,cis-muconic acid; 2-HMS, 2-hydroxymuconic semialdehyde; $K_{\mathrm{m}}$, Michaelis-Menten constant; MSM, mineral salts medium; $V_{\max }$ maximum velocity 
coccus strain was determined and compared with those of other known C23Os.

\section{EXPERIMENTAL PROCEDURES}

Media and culture conditions. Planococcus sp. strain $\mathrm{S} 5$, isolated from activated sludge of a sewage treatment plant in Bytom Miechowice, Poland (Labuziek et al., 2003), was enriched in mineral salts medium (MSM) containing (g L $\left.{ }^{-1}\right): \mathrm{Na}_{2} \mathrm{HPO}_{4} \cdot 12 \mathrm{H}_{2} \mathrm{O} 3.78, \mathrm{KH}_{2} \mathrm{PO}_{4} 0.5$, $\mathrm{NH}_{4} \mathrm{Cl} 5, \mathrm{MgSO}_{4} \cdot 7 \mathrm{H}_{2} \mathrm{O} 0.2,0.01$ yeast extract. After autoclaving, phenol was added to the medium as the sole carbon source. Cultures were incubated at $30^{\circ} \mathrm{C}$ with agitation at $125 \mathrm{rpm}$ for 24 hours. Analytical grade phenol was obtained from MERCK (Germany). All other chemicals used in this study were of the highest analytical grade available.

Phenol degradation by Planococcus sp. strain S5. For phenol degradation experiments, bacterial cultures in MSM were inoculated to the final optical density of about 0.1 at $\lambda=600 \mathrm{~nm}$ into $100 \mathrm{~mL}$ of liquid MSM medium with phenol (1-4 mM) and then incubated as above for 9 hours. Culture samples were collected every hour and $\mathrm{OD}_{600 \mathrm{~mm}}$ was measured. The concentration of phenol was determined with a colorimetric method using p-nitroaniline (Lurie \& Rybnikova, 1986).

Enzyme assays. Cells in MSM liquid medium (with 1-4 $\mathrm{mM}$ phenol as the sole carbon source) were harvested in the late exponential growth phase and centrifuged at $4500 \times g$ for $15 \mathrm{~min}$ at $4^{\circ} \mathrm{C}$. Subsequently, the cells were washed with $50 \mathrm{mM}$ phosphate buffer, $\mathrm{pH} 7.5$, resuspended in the same buffer at an $\mathrm{OD}_{600}$ of 1.0 and disrupted by pulsed sonication (Vibra Cell TM) 6 times for $15 \mathrm{~s}$ each. The disrupted cell suspension was centrifuged at $9000 \times g$ for $30 \mathrm{~min}$ at $4^{\circ} \mathrm{C}$ to remove cell debris. The clear supernatant was used as a crude extract for enzymes assays (Hegeman, 1966).

The activity of catechol 1,2-dioxygenase was determined spectrophotometrically at $260 \mathrm{~nm}$ by quantitating the formation of cis,cis-muconic acid (CCMA) $\left(\varepsilon_{\text {CCMA }}\right.$ $\left.=16800 \mathrm{M}^{-1} \mathrm{~cm}^{-1}\right)$ at $40^{\circ} \mathrm{C}$. The reaction mixture contained $20 \mu \mathrm{L}$ of catechol $(50 \mathrm{mM}), 67 \mu \mathrm{L}$ of $\mathrm{Na}_{2}$ EDTA $(20 \mathrm{mM}), 893 \mu \mathrm{L}$ of phosphate buffer $\mathrm{pH} 7.5(50 \mathrm{mM})$ and $20 \mu \mathrm{L}$ of crude bacterial extract in a total volume of $1 \mathrm{~mL}$ (Hegeman, 1966). The crude enzyme extract was incubated with $5 \% \mathrm{H}_{2} \mathrm{O}_{2}$ prior to the determination of catechol 1,2-dioxygenase activity to inactivate catechol 2,3-dioxygenase (Nakazawa \& Yokota, 1973).

In order to determine catechol 2,3-dioxygenase activity, the formation of 2-hydroxymuconic semialdehyde (2-HMS) was measured at $375 \mathrm{~nm}\left(\varepsilon_{2-\mathrm{HMS}}=36000 \mathrm{M}^{-1}\right.$ $\mathrm{cm}^{-1}$ ) in a reaction mixture containing $20 \mu \mathrm{L}$ of catechol $(50 \mathrm{mM}), 960 \mu \mathrm{L}$ of phosphate buffer $\mathrm{pH} 7.5(50 \mathrm{mM})$ and $20 \mu \mathrm{L}$ of crude extract in a total volume of $1 \mathrm{~mL}$ at $40^{\circ} \mathrm{C}$ (Feist \& Hegeman, 1969). Control reactions (without crude extract) were performed for each assay. Protein concentrations of the crude extract was determined by the Bradford method (Bradford, 1976). One unit of $\mathrm{C} 12 \mathrm{O}$ and $\mathrm{C} 23 \mathrm{O}$ activity was defined as the enzyme amount generating $1 \mu \mathrm{mol}$ of product per minute at $40^{\circ} \mathrm{C}$. The specific activity is given in $\mathrm{U}$ per gram of protein.

Substrate specificity of catechol 2,3-dioxygenase. The substrate specificity of the catechol 2,3-dioxygenase was examined with 3-methylcatechol, 4-methylcatechol, and 4-chlorocatechol. The aromatic ring cleavage was determined spectrophotometrically by measuring the increase in the absorbance at the corresponding wave- length of each meta-cleavage product formed. The activity of $\mathrm{C} 23 \mathrm{O}$ was assayed under the reaction conditions described above, using the aromatic compounds tested instead of catechol as a substrate. The molar extinction coefficient used for the product from 3-methylcatechol was $13800 \mathrm{M}^{-1} \mathrm{~cm}^{-1}$ (at $388 \mathrm{~nm}$ ), from 4-methylcatechol $28100 \mathrm{M}^{-1} \mathrm{~cm}^{-1}$ (at $382 \mathrm{~nm}$ ) (Bayly et al., 1966), and from 4-chlorocatechol $40000 \mathrm{M}^{-1} \mathrm{~cm}^{-1}$ (at $379 \mathrm{~nm}$ ) (Bae et al., 1996).

pH and temperature optima of catechol 2,3-dioxygenase. The effect of $\mathrm{pH}$ on catechol 2,3-dioxygenase activity was determined by measuring the activity at $40^{\circ} \mathrm{C}$ over the $\mathrm{pH}$ range of $1.0-10.8$ using the following buffers: $0.05 \mathrm{M}$ glycine- $\mathrm{HCl}(\mathrm{pH} 1.0$ to 2.0), 0.05 M phosphate-citrate ( $\mathrm{pH} 3.0$ to 5.0), 0.05 M Sörensen's phosphate ( $\mathrm{pH} 6.0$ to 8.0) and $0.05 \mathrm{M}$ borate ( $\mathrm{pH} 9.0)$.

The optimum temperature was determined by assaying the enzyme activity at various temperatures $\left(5-90^{\circ} \mathrm{C}\right)$ in $50 \mathrm{mM}$ Tris/ $\mathrm{HCl}$ buffer ( $\mathrm{pH} 8.0)$. The enzyme and substrate solutions were pre-incubated, mixed and the enzymatic reaction was then carried out at the same temperature.

Determination of temperature stability. The thermal stability of the enzyme was determined by incubating the enzyme and enzymatic reaction mixtures at $40^{\circ} \mathrm{C}$, $50^{\circ} \mathrm{C}$ and $60^{\circ} \mathrm{C}$ for $60 \mathrm{~min}$ and measuring the activity at $5,10,15$ and $20 \mathrm{~min}$ of incubation at the same temperatures. Additionally, activity of the enzyme incubated at $40^{\circ} \mathrm{C}$ was measured after 30 and 60 min of incubation.

Determination of kinetic constants of catechol 2,3-dioxygenase. The catalytic parameters (MichaelisMenten constant, $K_{\mathrm{m}}$, and maximum velocity, $\left.V_{\max }\right)$ were calculated by measuring the initial linear rates of the enzymatic reaction after the addition of different concentrations of catechol ranging from 0 to $200 \mu \mathrm{M}$ at $40^{\circ} \mathrm{C}$. Three independent measurements were carried out for each substrate concentration. $K_{\mathrm{m}}$ and $V_{\max }$ were calculated from Haldane iteration.

Identification and sequencing of catechol 2,3-dioxygenase gene. Plasmid and chromosomal DNA extraction, gel electrophoresis and PCR were performed by standard procedures (Sambrook et al., 1989). The $\mathrm{C} 23 \mathrm{O}$ gene was amplified using primers: 2,3D_zewF (ATGAAAAAAGGCGTAATGCGC) as forward and 2,3D_zewR (AGCACGGTCATGAAACGTTCGT'TC) as the reverse primer designed based on the regions of catechol 2,3-dioxygenases with high sequence conservation allowing amplification of the entire gene (Wojcieszyńska et al., 2011). Primers were purchased from IBB PAN (Warsaw, Poland). PCR amplification was carried out in a PTC-150 MiniCycler (MJ Research, USA). PCR reactions were performed in $25 \mu \mathrm{L}$ volumes containing approximately $0.1 \mu \mathrm{g}$ of template DNA (plasmid or chromosomal DNA), $0.5 \mu \mathrm{M}$ of each primer, $1 \times$ Pfu buffer (MBI Fermentas), 3\% (v/v) DMSO (Sigma), $0.2 \mathrm{mM}$ of each dNTP, $1 \mathrm{U}$ Pfu DNA polymerase (MBI Fermentas). PCR amplification was performed under the following conditions: initial denaturing $5 \mathrm{~min}$ at $94^{\circ} \mathrm{C} ; 10$ cycles of $1 \mathrm{~min}$ at $94^{\circ} \mathrm{C}, 30 \mathrm{~s}$ at $59^{\circ} \mathrm{C}, 1 \mathrm{~min}$ at $72^{\circ} \mathrm{C} ; 10$ cycles of $1 \mathrm{~min}$ at $94^{\circ} \mathrm{C}, 30 \mathrm{~s}$ at $57^{\circ} \mathrm{C}, 1 \mathrm{~min}$ at $72^{\circ} \mathrm{C} ; 15$ cycles of $1 \mathrm{~min}$ at $94^{\circ} \mathrm{C}, 30 \mathrm{~s}$ at $55^{\circ} \mathrm{C} 1 \mathrm{~min}$ at $72^{\circ} \mathrm{C}$ plus an additional $5 \mathrm{~min}$ elongation at $72^{\circ} \mathrm{C}$. Aliquots $(10 \mu \mathrm{L})$ of the PCR products were analyzed by electrophoresis on a $1.0 \%$ agarose gel stained with $0.5 \mu \mathrm{g} \mathrm{mL}-1$ ethidium bromide. Gene sequencing was performed using the Big Dye Terminator Cycle Sequencing Kit (Applied Biosystem) and an AbiPrism_3100 Genetic Analyzer. Computer analysis and processing of sequence information were performed with the program Chromas LITE (Technely- 
sium Pty, Tewantin, Australia). The obtained sequence of catechol 2,3-dioxygenase gene was compared with sequences available at the NCBI data base followed by multiple sequence alignment using the CLC FreeWorkbench software (CLC Bio A/S, Aarhus, Denmark). The nucleotide sequence of the catechol 2,3-dioxygenase gene from Planococcus sp. strain S5 has been deposited in the GenBank database of NCBI under the accession number HQ223337.

\section{RESULTS AND DISCUSSION}

\section{Degradation of phenol by strain S5}

Planococcus strain S5 was grown in MSM supplemented with 1-4 mM phenol. When S5 was grown with the initial phenol concentration of $1 \mathrm{mM}$ or $2 \mathrm{mM}$, the phenol was degraded completely within 5 or 7 hours, respectively (Fig. 1A, B). At higher initial phenol concentrations in the medium $(3-4 \mathrm{mM})$, the lag period of the culture increased in comparison to that growing at lower phenol concentrations, which could be connected with an inhibitory effect of high concentrations of phenol. However, the maximum growth of bacterial biomass was observed under high phenol concentrations (Fig. 1C, D).

Depending on the initial phenol concentration, an activity of both $\mathrm{C} 12 \mathrm{O}$ and $\mathrm{C} 23 \mathrm{O}$ or only $\mathrm{C} 23 \mathrm{O}$ was observed in the crude cell extract. When cells were growing on $1 \mathrm{mM}$ phenol, both enzymes were active but the activity of $\mathrm{C} 23 \mathrm{O}$ was slightly lower (Table 1). In the pres-
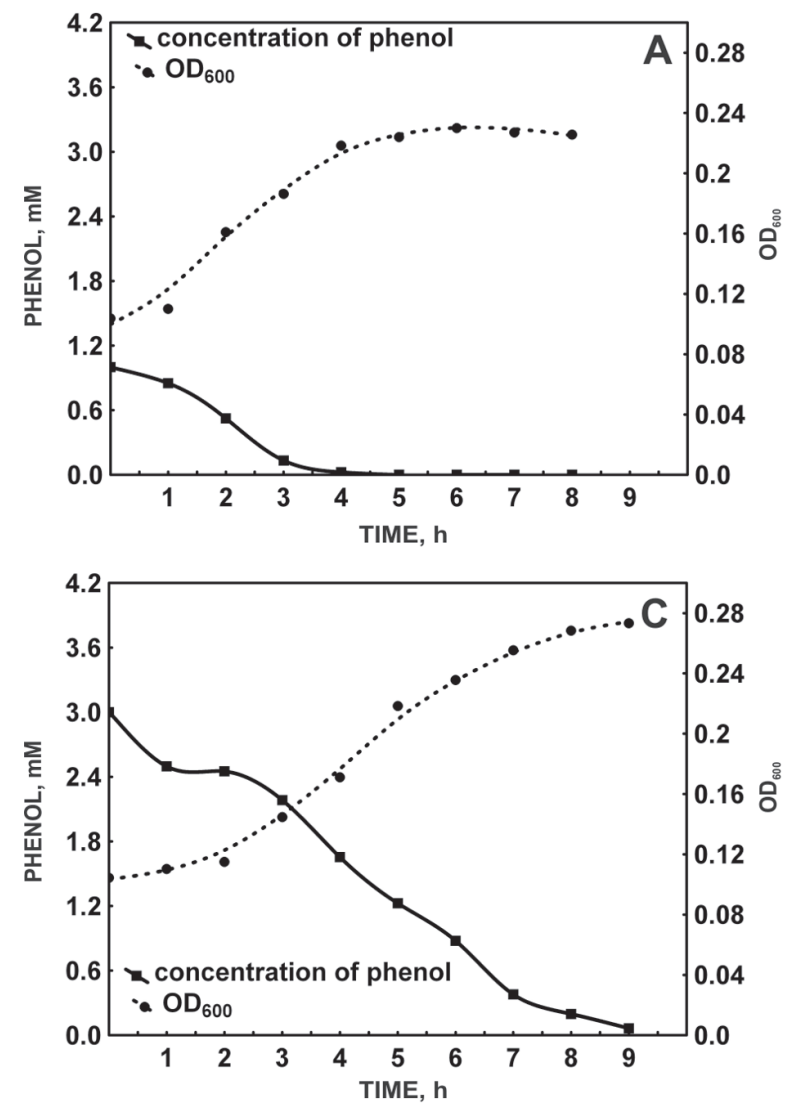

Table 1. Catechol 1,2-dioxygenase and catechol 2,3-dioxygenase activity in cell-free extracts of Planococcus sp. strain S5 grown on different initial phenol concentrations

\begin{tabular}{lll}
\hline \multirow{2}{*}{$\begin{array}{l}\text { Initial phenol con- } \\
\text { centration }(\mathrm{mM})\end{array}$} & \multicolumn{2}{l}{ Specific activitya $\left(\mathrm{U} \mathrm{g}^{-1}\right.$ protein $)$} \\
\cline { 2 - 3 } & $\begin{array}{l}\text { Catechol } \\
\text { 1,2-dioxygenase }\end{array}$ & $\begin{array}{l}\text { Catechol } \\
\text { 2,3-dioxygenase }\end{array}$ \\
\hline 1 & $16.6 \pm 0.75$ & $13.6 \pm 0.69$ \\
2 & $10.8 \pm 0.76$ & $22.0 \pm 0.60$ \\
3 & $0.00 \pm 0.00$ & $41.5 \pm 0.58$ \\
4 & $0.00 \pm 0.00$ & $43.6 \pm 0.66$ \\
\hline
\end{tabular}

aS5 strain was grown in $250 \mathrm{~mL}$ MSM containing 1-4 mM phenol to stationary phase before the enzyme activity determination. Data are expressed as mean \pm standard deviation $(n=3)$.

ence of $2 \mathrm{mM}$ phenol, both enzymes were induced and the activity of $\mathrm{C} 23 \mathrm{O}$ was twice that of $\mathrm{C} 12 \mathrm{O}$ (Table 1 ). Generally, degradation of phenol occurs either through the ortho- or meta-cleavage pathway (Dong et al., 1992; $\mathrm{Ng}$ et al., 1994; Powlowski \& Shingler, 1994; Aneez Ahamad et al., 1996; Duffner et al., 2000). Simultaneous induction of both enzymes splitting the catechol ring was observed by Heinaru et al. (2000) in two out of 39 phenol- degrading strains, and by Djokić et al. (2011a, b) in two bacilli strains designated as PS1 and PS11. Activity of both enzymes was also determined in Comamonas strain PND-3 and Cupriavidus strain PND-6 (Dong et al., 2008). However, in contrast to our results, the activity of C23O from the PND-3 and PND-6 strains was sig-
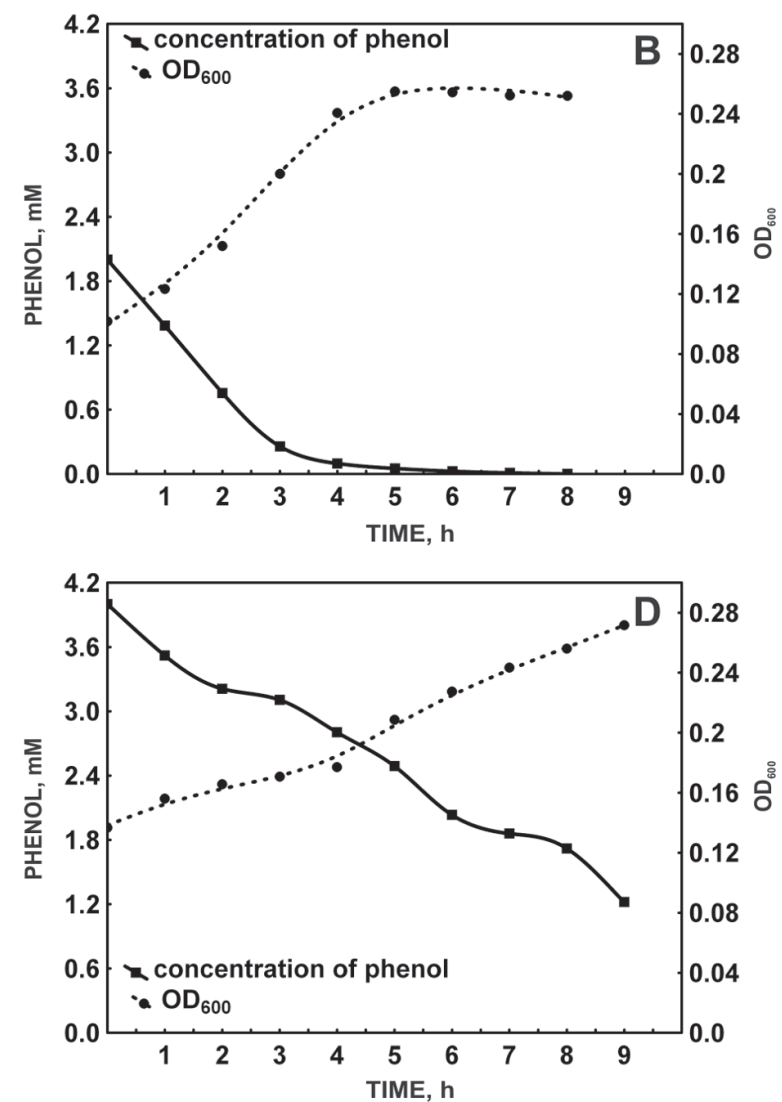

Figure 1. Time-course of phenol degradation and growth curve for Planococcus sp. S5 strain in media with different initial phenol concentration.

Liquid MSM contained initially $1 \mathrm{mM}$ (A), $2 \mathrm{mM}$ (B), $3 \mathrm{mM}$ (C) or $4 \mathrm{mM}$ (D) phenol. The results are average of triplicate independent experiments. 

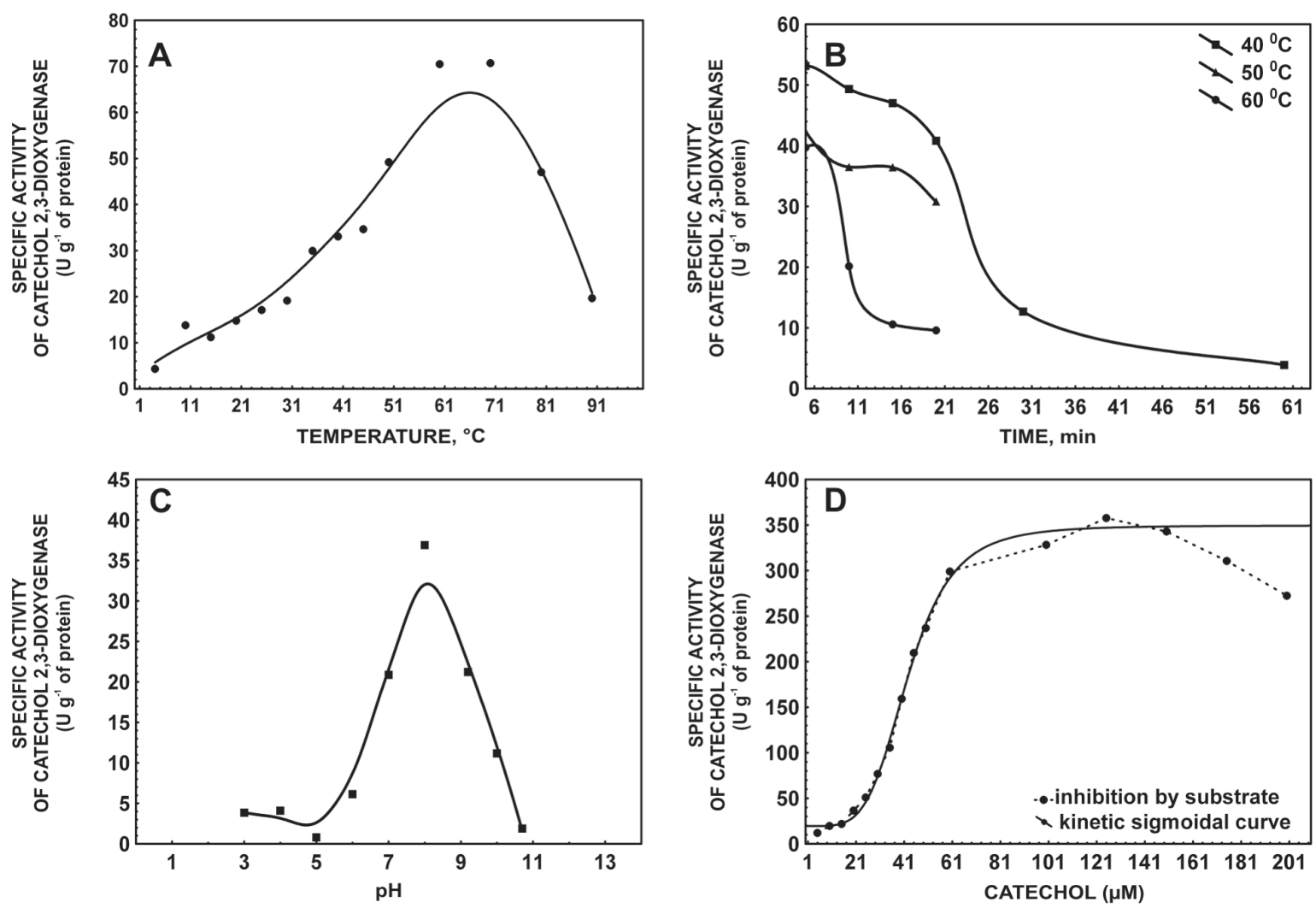

Figure 2. Effect of various factors on catechol 2,3-dioxygenase activity in Planococcus $s p$. S5 cell extract

(A) Ttemperature; (B) thermal stability; (C) $\mathrm{pH}$; and (D) substrate concentration. Data points are averages of three independent experiments.

nificantly lower than that of $\mathrm{C} 12 \mathrm{O}$ from those strains. At 3 or $4 \mathrm{mM}$ initial phenol concentration in growth medium only the activity of $\mathrm{C} 23 \mathrm{O}$ was observed in Planococcus crude extract (Table 1). It is generally known that $\mathrm{C} 23 \mathrm{O}$, the meta-pathway enzyme, is induced by the substrate while the ortho-cleavage pathway is induced by cis, cis-muconate, the product of the catechol ring fission (Williams et al., 1975; Song et al., 2000; Cao et al., 2008). When the S5 strain was grown in mineral medium with glucose, no activity of $\mathrm{C} 23 \mathrm{O}$ and slight activity of $\mathrm{C} 12 \mathrm{O}$ were observed (data not shown). As a result of the minimal activity of $\mathrm{C} 12 \mathrm{O}$, cis, cis-muconate was produced. Thus, at lower phenol concentrations both pathways could coexist in the same cell. Higher concentrations of phenol increase $\mathrm{C} 23 \mathrm{O}$ expression, which results in the conversion of catechol into 2-hydroxymuconic semialdehyde and does not allow the accumulation of cis, cis-muconate. Consequently, this inhibits the induction of the ortho-pathway enzyme. Induction of the meta-pathway enzymes at higher concentrations of an aromatic substrate was also observed by Loh \& Chua (2002) and Cao et al. (2008) during their studies on benzoate degradation by Pseudomonas putida ATCC49451. Benzoate is a known ortho-pathway inducer. It is speculated that induction of the meta-pathway at high concentrations of this substrate could be connected with accumulation of dihydroxybenzoate, a product of benzoate hydroxylation (Loh \& Chua, 2002).

\section{Catechol 2,3-dioxygenase activity and substrate specificity}

Lower initial phenol concentrations induced both $\mathrm{C} 12 \mathrm{O}$ and $\mathrm{C} 23 \mathrm{O}$ activity (Table 1 ). In the presence of 4
$\mathrm{mM}$ phenol only the activity of $\mathrm{C} 23 \mathrm{O}$ was observed ( $\mathrm{Ta}$ ble 1). Phenol at this concentration was used in studies on the enzymatic activity, substrate specificity and kinetic parameters of catechol 2,3-dioxygenase.

The aromatic ring-fission activity of $\mathrm{C} 23 \mathrm{O}$ from Planococcus sp. S5 was tested at different temperatures and with buffers of various $\mathrm{pH}$ (see Materials and Methods). The effect of temperature on the enzyme activity was investigated in the range $5-90^{\circ} \mathrm{C}$. Although the enzyme exhibited the highest activity at $60^{\circ} \mathrm{C}$ (Fig. 2A), it was unstable at that temperature. The half-life of the enzyme at $60^{\circ} \mathrm{C}$ was only $10 \mathrm{~min}$ (Fig. 2B). The enzyme has lost about $30 \%$ of its activity after 20 minutes at $50^{\circ} \mathrm{C}$ and its activity could still be detected even at $90^{\circ} \mathrm{C}$ (Fig. 2A). A slightly higher optimum temperature was observed for the $\mathrm{C} 23 \mathrm{O}$ enzyme from Bacillus thermoleovorans A2 (Milo et al., 1999). Its half-life at $70^{\circ} \mathrm{C}$ was $1.5 \mathrm{~min}$ under aerobic condition and $10 \mathrm{~min}$ in a nitrogen atmosphere (Milo et al., 1999). C23Os isolated from Pseudomonas strains ZJF08 and S-47 were optimally active at $40^{\circ} \mathrm{C}$ and $30-$ $35^{\circ} \mathrm{C}$, respectively ( $\mathrm{Kim}$ et al., 1997; Zou et al., 2007).

The optimal $\mathrm{pH}$ for the $\mathrm{C} 23 \mathrm{O}$ from strain $\mathrm{S} 5$ was determined using catechol as a substrate. The enzyme showed the highest activity (38 $\mathrm{U} \mathrm{g}^{-1}$ protein) at $\mathrm{pH}$ 8.0 (Fig. 2C), which is similar to catechol 2,3-dioxygenase from Pseudomonas sp. AW-2 (Murakami et al., 1998). However, in contrast to $\mathrm{C} 23 \mathrm{O}$ from strain S5, the dioxygenase from Pseudomonas sp. AW-2 was stable at $\mathrm{pH}$ 6.0-7.5. The optimal $\mathrm{pH}$ for $\mathrm{C} 23 \mathrm{O}$ from the thermoacidophilic Sulfolobus solfataricus strain 98/2 was 7.0-7.5. The enzyme was still 65\% active at $\mathrm{pH} 8.0,61 \%$ active at $\mathrm{pH}$ 9.0 and 29\% active at $\mathrm{pH} 4.0$ (Murakami et al., 1998), while C23O from strain S5 lost 90\% of its original specific activity under acidic condition and about 50\% at 
Table 2. Activity of catechol 2,3-dioxygenase with different substrates

\begin{tabular}{lll}
\hline Substrate & $\begin{array}{l}\text { Specific activity } \\
\left(\mathrm{U} \mathrm{g}^{-1} \text { protein }\right)\end{array}$ & $\begin{array}{l}\text { Relative activity } \\
(\%)\end{array}$ \\
\hline catechol & $13.4 \pm 0.42$ & 100.00 \\
3-methylcatechol & $1.8 \pm 0.14$ & 13.67 \\
4-methylcatechol & $14.2 \pm 0.75$ & 106.33 \\
4-chlorocatechol & $27.2 \pm 0.04$ & 203.80
\end{tabular}

aCatechol 2,3-dioxygenase activity was assayed spectrophotometrically at $375 \mathrm{~nm}$. Data are expressed as mean \pm standard deviation $(n=3)$. bExpressed as percentage of specific activity with catechol.

pH 9.0 (Fig. 2C). Catechol 2,3-dioxygenase isolated from another thermophilic strain Bacillus thermoleovorans A2 showed the highest activity at pH 7.2 (Milo et al., 1999).

In order to calculate $K_{\mathrm{m}}$ and $V_{\max }$, the activity of catechol 2,3-dioxygenase from Planococcus sp. S5 was measured at different substrate concentrations as detailed in materials and methods (Fig. 2D). The $K_{\mathrm{m}}$ and $V_{\max }$ values were $42.70 \mu \mathrm{M}$ and $329.96 \mathrm{mU}$, respectively. Much lower $K_{\mathrm{m}}$ values of $4.0,1.4$ and $11 \mu \mathrm{M}$ were observed for purified catechol 2,3-dioxygenase from Psendomonas sp. G7, Pseudomonas putida mt-2 and Pseudomonas sp. ND6 (Cerdan et al., 1995; Jiang et al., 2004), while the $K_{\mathrm{m}}$ of catechol 2,3-dioxygenase from Stenotrophomonas maltophilia $\mathrm{KB} 2$ crude extract was two-fold higher than that of the enzyme from S5 strain (Wojcieszyńska et al., 2011). During our studies on the kinetic properties of catechol 2,3-dioxygenase, enzyme inhibition was observed at $>120 \mu \mathrm{M}$ substrate (Fig. 2D). Inhibition of catechol 2,3-dioxygenase at lower concentrations of catechol (above $2 \mu \mathrm{M}$ ) was described by Takeo et al. (2007) for the wild-type enzyme from an aniline-degrading strain Acinetobacter sp. YAA.

Since the aromatic ring fission by catechol 2,3-dioxygenases occurs via an electrophilic aromatic substitution mechanism (Bugg, 2003), to determine the substrate specificity of $\mathrm{C} 23 \mathrm{O}$ from Planococcus sp. S5 substrates with either activating (3-methylcatechol, 4-methylcatechol) or deactivating (4-chlorocatechol) substituents were used. Additionally, Klečka \& Gibson (1981) and Polissi \& Harayama (1993) have observed that intermediates of chloro- and methylcatechols inactivate $\mathrm{C} 23 \mathrm{O}$ s by chelating the divalent kations necessary for its activity. Moreover, inactivation of these enzymes can be caused by oxidation of the ferrous iron in the active site (Riegert et al., 2001). The substrate specificity of C23O from Planococcus strain S5 with the catecholic compounds tested are shown in Table 2. The enzyme prefered catechols with a substituent in the para-position (4-chlorocatechol, 4-methylcatechol) over the meta position. It showed a remarkably high relative activity towards 4-chlorocatechol $(203 \%$ of that with catechol). The activity towards 4-methylcatechol was comparable to that to catechol, while only marginal activity was detected with 3-methylcatechol $(13.4 \%$ of that with catechol). The high activity towards 4-chlorocatechol distinguishes the dioxygenase studied from other C23Os (Kim et al., 1997; Milo et al., 1999).

Low preference for 3-methylcatechol was also observed for C23O from S. solfataricus (Chae et al., 2007), while 2,3-dioxygenases from P. putida UCC2 (Wallis \& Chapman, 1990) and Rhodococcus sp. strain DK17 (Kim et al., 2005) cleaved 3-methylcatechol at a higher rate than catechol. Cho et al. (2010) have revealed that in substrate-bound methylcatechol 2,3-dioxygenase from strain DK17 3-methylcatechol interacts with the iron via a single hydroxyl group. The $\beta$-hairpin structure of the active $\mathrm{C}$-domain of the enzyme forms part of the substrate binding pocket, responsible for the substrate specificity as well as its correct positioning in the active site. Based on the activities of $\mathrm{C} 23 \mathrm{O}$ from strain $\mathrm{S} 5 \mathrm{ob}-$ served with para- and meta-substituted catechols as substrates, we assumed that the active site of the enzyme differed from that of $\mathrm{C} 23 \mathrm{O}$ from strain DK17. Probably substituents in the meta-position comprise a steric hindrance for the correct orientation of the substrate in the active site of $\mathrm{C} 23 \mathrm{O}$ from Planococcus sp. S5, resulting in low activity against 3-methylcatechol. Chloro- and methylcatechols are substrates that cause inactivation of catechol 2,3-dioxygenases (Bartels et al., 1984; Takeo et al., 2007). The high activity of $\mathrm{C} 23 \mathrm{O}$ from Planococcus sp. S5 against 4-chlorocatechol and 4-methylcatechol, suggests the presence of a mechanism for reactivation of inactivated enzyme in strain S5. Reactivation of extradiol enzymes by the action of a protein similar to ferredoxin was described earlier by Polissi \& Harayama (1993) and Hugo et al. (1998). However, such an assumption needs to be verified by a detailed analysis of the entire operon responsible for phenol degradation in strain S5.

\section{Nucleotide sequence of catechol 2,3-dioxygenase gene}

Genes encoding catechol 2,3-dioxygenases are located on plasmids (Cerdan et al., 1995; Stilwell et al., 1995; Yrjälä et al., 1997; Jiang et al., 2004) or, as in Pseudomonas sp. strain KL28 and Comamonas testosteroni TA441, on the chromosome (Arai et al., 2000; Jeong et al., 2003). Our previous studies indicate that strain S5 contains plasmid DNA (Labużek et al., 2003). Therefore we applied PCR to amplify catechol 2,3-dioxygenase-encoding gene from Planococcus sp. S5 using primers 2,3D_zewF and 2,3D_ zewR and plasmid or chromosomal DNA as a template. A PCR product of about 900 bp was successfully obtained only with plasmid DNA as template indicating that the gene encoding catechol 2,3-dioxygenase in strain S5 is located on the plasmid. Sequencing of that PCR product resulted in a 917-nucleotide sequence (GenBank ID: HQ223337) which showed $100 \%$ homology with the sequence of the C23O gene from Pseudomonas sp. PD10, $99 \%$ homology with genes for C23Os from Pseudomonas CF600, Pseudomonas sp. PD7, or P. aeruginosa and 95\% with the gene from $P$. mendocina PC. It is interesting to note that the extradiol dioxygenase from a Gram-positive strain shows such a high homology with enzymes from the Gram-negative Pseudomonas strains. A remarkable degree of homology of nucleotide and amino acid sequence of $\mathrm{C} 23 \mathrm{O}$ from Gram-positive and Gram-negative strains was also indicated by Candidus et al. (1994) for Rhodococcus rhodochrous CTM. Such a high homology of nucleotide sequences indicates a very recent common genetic origin of all these enzymes and horizontal transfer of the gene coding for catechol 2,3-dioxygenase in many bacterial strains. Such gene transfer of $\operatorname{tdn} C$ encoding C23O from Pseudomonas putida UWC (pD10, pQKH6) to P. fluorescens, P. chlororaphis, P. aureofaciens and a Bordetella-like species has been reported by Hill et al. (1994). Horizontal transfer of the C23O gene was also observed by Wang et al. (2007) between endophytic and rhizosphere bacteria and by Jussila et al. (2007) between Pseudomonas and Rhizobium.

In summary, the Gram-positive Planococcus sp. strain S5 exhibited simultaneously catechol 1,2- and 2,3-dioxygenase activities when grown on low phenol concentra- 
tions, while at higher initial phenol concentrations only the activity of $\mathrm{C} 23 \mathrm{O}$ was detected. The extradiol enzyme from strain S5 degrading $4 \mathrm{mM}$ phenol was optimally active at $60^{\circ} \mathrm{C}$ and $\mathrm{pH}$ 8.0. A remarkable preference of this dioxygenase for catechols with a substituent in the para-position, especially towards 4-chlorocatechol, distinguishes it from other C23Os from Gram-positive and Gram-negative bacteria. The properties of the described enzyme make it useful for bioremediation applications.

\section{Acknowledgements}

We thank Dr. Renata Zub (Department of Molecular Biology, Institute of Oncology, Warsaw, Poland) for DNA sequencing. Ms. Kornelia Kozioł is acknowledged for excellent technical assistance.

\section{REFERENCES}

Aneez Ahamad PYA, Kunhi AAM (1996) Degradation of phenol through orto-cleavage pathway by Pseudomonas stutzeri strain SPC2. Lett Appl Microbiol 45: 26-29.

Arai H, Ohishi T, Chang MY, Kudo T (2000) Arrangement and regulation of the genes for meta-pathway enzymes required for degradation of phenol in Comamonas testosteroni TA441. Microbiology 146: 1707-1715.

Bae HS, Lee M, Kim JB, Lee ST (1996) Biodegradation of the mixtures of 4-chlorophenol and phenol by Comamonas testosteroni CPW301. Biodegradation 7: 463-469.

Bartels I, Knackmuss HJ, Reineke W (1984) Suicide inactivation of catechol 2,3-dioxygenase from Pseudomonas putida $\mathrm{mt}-2$ by 3-halocatechols. Appl Environ Microbiol 47: 500-505.

Bayly RC, Dagley S, Gibson DT (1966) The metabolism of cresols by species of Pseudomonas. Biochem J 101: 293-301.

Bradford MM (1976) A rapid and sensitive method for the quantitation of microgram quantities of protein utilizing the principle of proteindye binding. Anal Biochem 72: 248-58.

Bugg TDH (2003) Dioxygenase enzymes: catalytic mechanisms and chemical models. Tetrahedron 59: 7075-101.

Bugg TDH, Ramaswamy S (2008) Non-heme iron-dependent dioxygenases: unraveling catalytic mechanism for complex enzymatic oxidation. Curr Opin Chem Biol 12: 134-140.

Candidus S, van Pee KH, Lingens F (1994) The catechol 2,3-dioxygenase gene of Rhodococcus rhodochrous CTM: nucleotide sequence, comparison with isofunctional dioxygenases and evidence for an activesite histidine. Microbiology 140: 321-330.

Cao B, Geng A, Loh K-C (2008) Induction of ortho- and meta- cleavage pathways in Pseudomonas in biodegradation of high benzoate concentration: MS identification of catabolic enzymes. Appl Microbiol Biotechnol 81: 99-107.

Cerdan P, Rekik M, Harayama S (1995) Substrate specificity differences between two catechol 2,3-dioxygenases encoded by the TOL and NAH plasmids from Pseudomonas putida. Eur I Biochem 229: 113-118.

Chae J-Ch, Kim E, Bini E, Zylstra GJ (2007) Comparative analysis of the catechol 2,3-dioxygenase gene locus in thermoacidophilic Archeon Sulfolobus solfataricus strain 98/2. Biochem Biopbys Res Commun 357: 815-819.

Cho HJ, Kim K, Sohn SY, Cho HY, Kim KJ, Kim MH, Kim D, Kim E, Kang BS (2010) Substrate binding mechanism of a type I extradiol dioxygenase. I Biol Chem 285: 34643-34652.

Chowdhury R, Sen AK, Karak P, Chatterjee R. Giri AK, Chaudhuri K. (2003) Isolation and characterization of an arsenic-resistant bacterium from a bore-well in West Bengal, India. Ann Microbiol 59: 253-258

Dalal S, Panigrahi DP, Randhawa GS, Dubey RC (2012) Molecular characterization of high-strength polycyclic aromatic hydrocarbon (PAH)-degrading and phenol-tolerant bacteria obtained from thermal power plant wastewater. Chem Ecol DOI: 10.1080/02757540.2011.650166.

Djokic L, Narancic T, Nikodinovic-Runic J, Savic M, Vasiljevic B (2011a) Isolation and characterization of four novel Gram-positive bacteria associated with the rhizosphere of two endemorelict plants capable of degrading a broad range of aromatic substrates. Appl Microbiol Biotechnol 91: 1227-1238.

Djokic L, Narancic T, Nikodinovic-Runic J, Bajkic S, Vasiljevic B (2011b) Four Bacillus sp. soil isolates capable of degrading phenol, toluene, biphenyl, naphthalene, and other aromatic compounds exhibit different aromatic catabolic potentials. Arch Biol Sci 63: 10571067.

Dong FM, Wang LL, Wang ChM, Cheng JP, He ZQ, Sheng ZJ, Shen RQ (1992) Molecular cloning and mapping of phenol degradation genes from Bacillus stearothermophilus FTDP-3 and their expression in Escherichia coli. Appl Environ Microbiol 58: 2531-2535.

Dong X, Hong Q, He L, Jiang X, Li S (2008) Characterization of phenol-degrading bacterial strains isolated from natural soil. Int Biodeter Biodegr 62: 257-262.

Duffner FM, Kirchner U, Bauer MP, Müller R (2000) Phenol/cresol degradation by the thermophilic Bacillus thermoglucosidansius A7: cloning and sequence analysis of five genes involved in the pathway. Gene 256: 215-221.

Engelhardt MA, Daly K, Swannell RPJ, Head IM (2001) Isolation and characterization of a novel hydrocarbon-degrading, Gram-positive bacterium, isolated from intertidal beach sediment, and description of Planococcus alkeanoclasticus sp. nov. J Appl Microbiol 90: 237-247.

Feist CF, Hegeman GD (1969) Phenol and benzoate metabolism by Pseudomonas putida: regulation of tangential pathways. J Bacteriol 100: 869-877.

Fortin P, Macpherson I, Neau D, Bolin J, Eltis L (2005) Directed evolution of a ring-cleaving dioxygenase for polychlorinated biphenyl degradation. J Biol Chem 280: 42307-42314.

Harayama S, Rekik M (1989) Bacterial aromatic ring-cleavage enzymes are classified into two different gene families. J Biol Chem 264: 15328-15333.

Hatta T, Mukerjee-Dhar G, Damborsky J, Kiyohara H, Kimbara K (2003) Characterization of a novel thermostable Mn(II)-dependent 2,3- dihydroxybiphenyl 1,2-dioxygenase from a polychlorinated biphenyl- and naphthalene-degrading Bacillus sp. JF8. J Biol Chem 278: 21483-21492.

Hegeman GD (1966) Synthesis of enzymes of mandelate pathways by Pseudomonas putida. Synthesis of enzyme by wild type. J Bacteriol 91: 1140-1150.

Heinaru E, Truu J, Stottmeister U, Heinaru A (2000) Three types of phenol and $p$-cresol catabolism in phenol and $p$-cresol-degrading bacteria isolated from river water continuously polluted with phenolic compounds. FEMS Microbiol Ecol 31: 195-205.

Hill KE, Fry JC, Weightman AJ (1994) Gene transfer in the aquatic environment: persistence and mobilization of the catabolic recombinant plasmid pDlO in the epilithon. Microbiology 140: 1555-1563.

Hugo N, Armengaud J, Gaillard J, Timmis KN, Jouanneau Y (1998) A novel $-2 \mathrm{FeS}-2 \mathrm{~S}$-ferrodoxin from Psendomonas putida $\mathrm{mt} 2$ promotes the reductive reactivation of catechols 2,3-dioxygenase. $J$ Biol Chem 17: 9622-9629.

Jacobucci DFC, Oriani MRG, Regina L (2009) Reducing COD level on oily effluent by utilizing biosurfactant-producing bacteria. Braz Arch Biol Technol 52: 1037-1042.

Jeong JJ, Kim JH, Kim ChK, Hwang I, Lee K (2003) 3- and 4-alkylphenol degradation pathway in Psendomonas sp. strain KL28: genetic organization of the lap gene cluster and substrate specificities of phenol hydroxylase and catechol 2,3-dioxygenase. Microbiology 149: 3265-3277.

Jiang Y, Yang X, Liu B, Zhao H, Cheng Q, Cai B (2004) Catechol 2,3-dioxygenase from Pseudomonas sp. ND6. Gene sequence and enzyme characterization. Biosci Biotechnol Biochem 68: 1798-1800.

Junca H, Plumeier I, Hecht HJ, Pieper DH (2004) Difference in kinetic behavior of catechol 2,3-dioxygenase variants from a polluted environment. Microbiology 150: 4181-4187.

Jussila MM, Zhao J, Suominen L, Lindström K (2007) TOL plasmid transfer during bacterial conjugation in vitro and rhizoremediation of oil compounds in vivo. Environ Pollut 146: 510-524.

Kalogeris E, Sanakis Y, Mamma D, Christakopoulos P, Kekos D, Stamatis H (2006) Properties of catechol 1,2-dioxygenase from Pseudomonas putida immobilized in calcium alginate hydrogels. Ensyme Microb Tech 39: 1113-1121.

Kasuga I, Nakajima F, Furumai H (2007) Diversity of catechol 2,3-dioxygenase genes of bacteria responding to dissolved organic matter derived from different sources in a eutrophic lake. FEMS Microbiol Ecol 61: 449-458.

Kim D, Chae JCh, Jang IY, Zylstra GJ, Kim YM, Kang BS, Kim EK (2005) Functional characterization and molecular modeling of methylcatechol 2,3-dioxygenase from o-xylene-degrading Rhodococcus sp. strain DK17. Biochem Biophys Res Commun 326: 880-886.

Kim KP, Seo DI, Min KH, Ka JO, Park YK, Kim ChK (1997) Characteristics of catechol 2,3-dioxygenase produced by 4-chlorobenzoate-degrading Pseudomonas sp. S-47. I Microbiol 35: 295-299.

Klečka GM, Gibson DT (1981) Inhibition of catechol 2,3-dioxygenase from Pseudomonas putida by 3-chlorocatechol. Appl Environ Microbiol 41: 1159-1165.

Łabużek S, Hupert- Kocurek K, Skurnik M (2003) Isolation and characterisation of new Planococcus sp. strain able for aromatic hydrocarbons degradation. Acta Microbiol Pol 52: 395-404.

Li W, Shi J, Wang X, Yuning H, Tong W, Ma L, Liu B, Cai B (2004) Complete nucleotide sequence and organization of the naphthalene catabolic plasmid pND6-1 from Pseudomonas sp. strain ND6. Gene 336: 231-240.

Li H, Liu YH, Luo N, Zhang XY, Luan TG, Hu JM, Wang ZY, Wu PC, Chen MJ, Lu JQ (2006) Biodegradation of benzene and its de- 
rivatives by a psychrotolerant and moderately haloalkaliphilic Planococcus sp. strain ZD22. Res Microbiol 157: 629-636.

Loh KC, Chua SS (2002) Ortho pathway of benzoate degradation in Pseudomonas putida: induction of meta pathway at high substrate concentrations. Enzyme Microbiol Technol 30: 620-626.

Lurie J, Rybnikova I (1986) Chemical analysis of industrial sewages. Gaschmizdat, Moscow (In Russian).

Ma H, Li G, Fang P, Zhang Y, Xu D (2010) Identification of phenoldegrading Nocardia sp. strain C-14-1 and characterization of its ringcleavage 2,3-dioxygenase. Int J Biol 2: 79-83.

Milo RE, Duffner FM, Muller R (1999) Catechol 2,3- dioxygenase from the thermophilic, phenol-degrading Bacillus thermoleovorans strain A2 has unexpected low thermal stability. Extremophiles 3: 185-190.

Müller Ch, Petruschka L, Cuypers H, Burchhardt G, Herrmann H (1996) Carbon catabolite repression of phenol degradation in Pseudomonas putidas mediated by the inhibition of the activator protein PhlR. J Bacteriol 178: 2030-2036.

Murakami S, Nakanishi Y, Kodama N, Takenaka S, Shinke R, Aoki K (1998) Purification, characterization, and gene analysis of catechol 2,3- dioxygenase from the aniline- assimilating bacterium Psendomonas species AW-2. Biosci Biotechnol Biochem 62: 747-752.

Nakazawa T, Yokota T (1973) Benzoate metabolism in Pseudomonas putida (arvilla) $\mathrm{mt}-2$ : demonstration of two benzoate pathways. I Bacteriol 115: 262-267.

Ng LCh, Shingle V, Sze ChCh, Poh ChL (1994) Cloning and sequences of the first eight genes of the chromosomally encoded (methyl) phenol degradation pathway from Pseudomonas putida P35X. Gene 151: 29-36.

Nithya C, Gnanalakshmi B, Pandian SK (2011) Assessment and characterization of heavy metal resistance in Palk Bay sediment bacteria. Mar Environ Res 71: 283-294.

Okuta A, Ohnishi K, Harayama S (1998) PCR isolation of catechol 2,3-dioxygenase gene fragments from environmental samples and their assembly into functional genes. Gene 212: 221-228.

Palaniandavar M, Mayilmurugan R (2007) Mononuclear non-hem iron(III) complex as functional models for catechol dioxygenases. Comptes Rendus Chimie 10: 366-379.

Polissi A, Harayama S (1993) In vivo reactivation of catechol 2,3-dioxygenase mediated by a chloroplast-type ferredoxin: a bacterial strategy to expand the substrate specificity of aromatic degradative pathways. EMBO J 12: 3339-3347.

Powlowski J, Shingler V (1994) Genetic and biochemistry of phenol degradation by Pseudomonas sp. CF600. Biodegradation 5: 219-236.

Riegert U, Bürger S, Stolz A (2001) Altering catalytic properties of 3-chlorocatechol-oxidizing extradiol dioxygenase from Sphingomonas xenophaga BN6 by random mutagenesis. I Bacteriol 183: 2322-2330.

Romano I, Giordano A, Lama L, Nicolaus B, Gambacorta A (2003) Planococcus rifietensis sp. nov, Isolated from Algal Mat Collected from a Sulfurous Spring in Campania (Italy). Sys Appl Microbiol 26: 357-366.

Sambrook J, Fritsch EF, Maniatis T (1989) Molecular cloning: A laboratory manual. 2nd edn. Cold Spring Harbor Laboratory Press, New York.

Sato S, Nam J-W, Kasuga K, Nojiri H, Yamane H, Omori T (1997) Identification and characterization of genes encoding carbazole $1,9 \mathrm{a}-$ dioxygenase in Pseudomonas sp. strain CA10. I Bacteriol 179: 48504858.

Sei K, Asano K, Tateishi N, Mori K, Ike M, Fujita M (1999) Design of PCR primers and gene probes for the general detection of bacterial populations capable of degrading aromatic compounds via catechol cleavage pathways. J Biosci Bioeng 88: 542-550.

Song J, Sung J, Kim YM, Zylstra GJ, Kim E (2000) Roles of the metaand ortho-cleavage pathways for the efficient utilization of aromatic hydrocarbons by Sphingomonas yanoikuyae B1. J Microbiol 38: 245-249.

Sprott GD, Larocque S, Cadotte N, Dicaire CJ, McGee M, Brisson JR (2003) Novel polar lipids of halophilic eubacterium Planococcus H8 and archaeon Haloferax volcanii. Biochim Biophys Acta 1633: 179-188.

Stillwell LC, Thurston SJ, Schneider RP, Romine MF, Fredrickson JK, Saffer JD (1995) Physical mapping and characterization of a catabolic plasmid from the deep-subsurface bacterium Sphingomonas sp. strain F199. J Bacteriol 177: 4537-4539.

Takeo M, Nishimura M, Shirai M, Takahashi H, Negoro S (2007) Purification and characterization of catechol 2,3-dioxygenase from the aniline degradation pathway of Acinetobacter sp. YAA and its mutant enzyme, which resist substrate inhibition. Biosci Biotechnol Biochem 71: 1668-1675.

Tancsics A, Szabó I, Baka E, Szoboszlay S, Kukolya J, Kriszt B, Marialigeti K (2010) Investigation of catechol 2,3-dioxygenase and 16S rRNA gene diversity in hypoxic, petroleum hydrocarbon contaminated groundwater. Sys Appl Microbiol 33: 398-406.

Vaillancourt FH, Bolin JT, Eltis LD (2006) The ins and outs of ringcleaving dioxygenases. Crit Rev Biochem Mol Biol 41: 241-67.

Viggiani A, Siani L, Notomista E, Birolo L, Pucci P, Donato D (2004) A The role of the conserved residues His-246, His-199, and Tyr255 in the catalysis of catechol 2,3-dioxygenase from Pseudomonas stutzeri OX1. J Biol Chem 279: 48630-48639.

Wallis M., Chapman S (1990) Isolation and partial characterization of an extradiol non-haem iron dioxygenase which preferentially cleaves 3-methylcatechol. Biochem J 266: 605-609.

Wang Y, Xiao M, Geng X, Liu J, Chen J (2007) Horizontal transfer of genetic determinants for degradation of phenol between the bacteria living in plant and its rhizosphere. Appl Microbiol Biotechnol 77: 733-739.

Wei J, Zhou Y, Xu T, Lu B, (2010) Rational design of catechol 2,3-dioxygenase for improving the enzyme characteristic. Appl Biochem Biotechnol 162: 116-126.

Williams PA, Catterall FA, Murray K (1975) Metabolism of naphthalene, 2-methylnaphthalene, salicylate and benzoate by Pseudomonas PG: Regulation of tangential pathways. J Bacteriol 124: 679-685.

Wojcieszyńska D, Hupert-Kocurek K, Greń I, Guzik U (2011) High activity catechols 2,3-dioxygenase from the cresols-degrading Stenotrophomonas maltophilia strain KB2. Int Biodeter Biodegr 65: 853-858.

Yrjälä K, Paulin L, Romantschuk M (1997) Novel oraganization of catechol meta-pathway genes in Sphingomonas sp. HV3 pSKY4 plasmid. FEMS Microbiol Lett 154: 403-408.

Zou Y, Wei J, Jiang T, Gao W, Ma Y, Wei D (2007) Characterisation of thermostable catechol 2,3-dioxygenase from phenanthrenedegrading Pseudomonas sp. strain ZJF08. Ann Microbiol 57: 503-508. 
